\title{
Proximate Analysis of Noodles with Substitution of Jackfruit Seed Flour and Branch Flour as Alternative Food for Diabetes Patients
}

\author{
Kenyo Alfiani Hestiningtyas ${ }^{1,}$ Hartati Eko Wardani ${ }^{2 *}$, Agung Kurniawan ${ }^{3}$ \\ ${ }^{1}$ Department of Public Health, Faculty of Sport Science, Universitas Negeri Malang, Malang, East Java, Indonesia \\ ${ }^{2}$ Department of Public Health, Faculty of Sport Science, Universitas Negeri Malang, Malang, East Java, Indonesia \\ ${ }^{3}$ Department of Public Health, Faculty of Sport Science, Universitas Negeri Malang, Malang, East Java, Indonesia \\ *Corresponding author. Email: hartati.eko.fik@um.ac.id
}

\begin{abstract}
Lifestyle is the riskiest cause for diabetes patients. One of easy processed food that are popular with the community is noodles. Jackfruit seed flour can be an alternative as a food product with high fibre content, and rice bran is a high-fibre and high-antioxidant food to ward off degenerative diseases such as diabetes. This study aimed to determine a suitable noodle formulation with jackfruit seed flour and rice bran flour seen from the proximate analysis test parameters. This study used the research and development method by using a procedural model. The analysis carried out was a test of water, ash, fat, protein, carbohydrate, and fibre content. The result showed that the best noodle formulation with adjustments to the dietary recommendations of diabetics regarding carbohydrates and crude fibre was in formulation 3 (30\%:5\%).
\end{abstract}

Keywords: proximate analysis, jackfruit seed flour, bran flour

\section{INTRODUCTION}

Diabetes is a chronic disease that causes the pancreas to not produce enough insulin (a hormone that regulates blood sugar or glucose) or when the body cannot effectively use the insulin it produces [1]. According to IDF data in 2019, around 463 million adults (20-79 years) were living with diabetes and this continues to increase by 2045 to 700 million people [2]. Looking at the 2018 Riskesdas data, the prevalence of diabetes mellitus in Indonesia is $2.0 \%$ in the population aged $>15$ years and East Java occupies the 5th province with the highest prevalence of diabetes mellitus in Indonesia [1]. The prevalence of diabetes that will continue to increase is due to many risk factors that can be grouped into three categories, namely socio-demographic, clinical/mental, and lifestyle factors [3]. According to WHO (2005), an unhealthy lifestyle is one of the top ten causes of death and disability in the world [4].

Now, public awareness of the importance of a healthy lifestyle is increasing. This causes changes in people's behavior patterns for the better, especially in the selection of food ingredients [5]. Various degenerative diseases such as diabetes mellitus, stroke, heart attack can make people more aware of the food they eat [6]. Healthy food choices need to be made to maintain blood glucose levels. One of the foods that can maintain blood glucose is highfiber foods. Fiber is known to help regulate blood glucose levels [7].

However, with the high activity of the community in recent decades, people also need foods that are easy to process, one of which is noodles. Noodles are a type of flour processed food that is favored by the public because the presentation is very easy and fast [8]. Instant noodles are generally made from wheat flour and contain low levels of antioxidant activity, crude fiber and dietary fiber (soluble and insoluble) [9]. Low fiber can cause a high Glycemic Index [10].

Jackfruit seed flour can be used as an alternative ingredient in making a food product. Jackfruit seed flour contains high nutritional value compared to the nutritional value of wheat flour [11]. Rice bran is one of the results of the rice milling process which is quite large in number. In addition, the Ministry of Agriculture (2002) also stated that the availability of rice bran in Indonesia could reach 4.5-5 million tons annually. In addition, rice bran contains antioxidants, multivitamins 
and high fiber for antidote to degenerative diseases and is also rich in starch, protein, fat, vitamins, and minerals [12].

In previous studies, rice bran flour was processed into instant noodle products, obtained in the addition of 5\% bran flour because it has good nutritional content compared to other formulas [13]. In a previous study for jackfruit seed flour combined with corn starch made into noodles, it was found that formula 3 (30\%:70\%) was the best formula that met SNI requirements [14].

In conclusion, noodles made from jackfruit seed flour and rice bran can increase the crude fiber content in noodles made from wheat flour to provide better functional value in noodle products. Therefore, this study aims to determine the nutritional content of the proximate test by developing noodles with jackfruit seed flour and rice bran flour as an alternative food for diabetics.

\section{METHOD}

This study uses research and development methods (research and development). According to Sugiyono (2016), the method by reviewing is to develop or produce a product with different specifications from other products [15]. Research and development is a p Developing a functional food ingredient for diabetics. In this research and development using a procedural model. The procedural model is a descriptive model, which outlines the steps that must be followed to produce a product [16]. This research was carried out in several stages by conducting the preparation stage, making jackfruit seed flour and bran flour, making substitute noodles for jackfruit seed flour and rice bran flour, and conducting proximate analysis. The instrument used is the proximate analysis result form according to the SNI standard 01-2987-1992. The research site for the process of making jackfruit seed flour, rice bran flour and noodles was carried out at the Nutrition Laboratory of Brawijaya University and proximate analysis at the Animal Husbandry and Nutrition Laboratory of Muhammadyah University, Malang. The researcher also conducted an ethical test at Brawijaya University with No. 68/EC/KEPK-S1/03/2021.

Table 1. Formulation of Noodles with Jackfruit Seed Flour and Rice Bran Flour

\begin{tabular}{|l|r|r|r|r|}
\hline Formulation & \multicolumn{1}{|c|}{ F0 } & \multicolumn{1}{|c|}{$\mathrm{F}$ 1 } & \multicolumn{1}{c|}{ F2 } & \multicolumn{1}{c|}{ F3 } \\
\hline $\begin{array}{l}\text { Medium } \\
\text { protein } \\
\text { flour }\end{array}$ & $180 \mathrm{~g}$ & $150 \mathrm{~g}$ & $130 \mathrm{~g}$ & $110 \mathrm{~g}$ \\
\hline $\begin{array}{l}\text { High } \\
\text { protein } \\
\text { flour }\end{array}$ & $180 \mathrm{~g}$ & $150 \mathrm{~g}$ & $130 \mathrm{~g}$ & $110 \mathrm{~g}$ \\
\hline $\begin{array}{l}\text { Jackfruit } \\
\text { seed flour }\end{array}$ & 0 & $40 \mathrm{~g}$ & $80 \mathrm{~g}$ & $120 \mathrm{~g}$ \\
\hline Rice bran & 0 & $20 \mathrm{~g}$ & $20 \mathrm{~g}$ & $20 \mathrm{~g}$ \\
\hline Starch & $40 \mathrm{~g}$ & $40 \mathrm{~g}$ & $40 \mathrm{~g}$ & $40 \mathrm{~g}$ \\
\hline Salt & $2 \mathrm{tsp}$ & $2 \mathrm{tsp}$ & $2 \mathrm{tsp}$ & $2 \mathrm{tsp}$ \\
\hline
\end{tabular}

\begin{tabular}{|l|r|r|r|r|}
\hline Formulation & \multicolumn{1}{|c|}{ F0 } & \multicolumn{1}{|c|}{ F1 } & \multicolumn{1}{|c|}{ F2 } & \multicolumn{1}{|c|}{ F3 } \\
\hline Egg & 1 item & 1 item & 1 item & 1 item \\
\hline Cooking oil & 4 tbsp & 4 tbsp & 4 tbsp & 4 tbsp \\
\hline Water khi & $2 \mathrm{tsp}$ & $2 \mathrm{tsp}$ & $2 \mathrm{tsp}$ & $2 \mathrm{tsp}$ \\
\hline Water & $100 \mathrm{ml}$ & $100 \mathrm{ml}$ & $100 \mathrm{ml}$ & $100 \mathrm{ml}$ \\
\hline
\end{tabular}

There are three formulations, namely 10:5 (F1), 20:5 (F2), 30:5 (F3) in the manufacture of jackfruit seed flour noodles and rice bran flour with one control formulation as a comparison. Researchers conducted expert validation to see the panelists' preference for the color, aroma, texture, and taste of the four noodle formulations made. The proximate analysis carried out by the researchers in this study included the analysis of water content, ash content, protein content, fat content, carbohydrate content, and fiber content. Then the results of the analysis will be compared with the standard SNI 01-2987-1992 to find the best product formulation of noodles substituted with jackfruit seed flour and rice bran flour.

\section{RESULTS AND DISCUSSION}

\subsection{Nutritional Content and Contribution to $R D A$}

The nutritional content of this noodle product with the substitution of jackfruit seed flour and bran flour was obtained from Nutrisurvey data which was adjusted to the dietary recommendations for diabetics. The recommendation for heavy meals for diabetics is $25-30 \%$ of the total energy calories consumed per day and adjusted for the content of noodles, namely carbohydrates (45-65\% of total calories per day). The nutritional content of the four formulations (F0, F1, F2, and F3) is as follows:

Table 2. Nutritional Content of Noodles Substituted with Jackfruit Seeds and Rice Bran

\begin{tabular}{|l|l|l|l|l|}
\hline & F0 & \multicolumn{1}{|c|}{ F1 } & F2 & F3 \\
\hline $\begin{array}{l}\text { Serving size } \\
\text { Number of } \\
\text { servings per pack }\end{array}$ & $\begin{array}{l}86 \text { gr } \\
1\end{array}$ & $\begin{array}{l}86 \text { gr } \\
1\end{array}$ & $\begin{array}{l}86 \text { gr } \\
1\end{array}$ & $\begin{array}{l}86 \text { gr } \\
1\end{array}$ \\
\hline $\begin{array}{l}\text { Total energy (kcal) } \\
\text { Protein(g) }\end{array}$ & 409.63 & 402 & 393.3 & 384.9 \\
Fat(g) & 9.65 & 9.39 & 8.87 & 8.34 \\
Carbohydrates (g) & 10.7 & 11.57 & 11.49 & 11.41 \\
Dietary fiber (g) & 67.18 & 62.6 & 59.05 & 55.82 \\
& 2.17 & 3.15 & 3.16 & 3.16 \\
\hline
\end{tabular}

Source: Nutrisurvey

The total energy produced from the four noodle formulations is derived from the percent of the Nutritional Needs (RDA) based on energy needs of 2150 kcal [17]. The total energy shows that there is a difference in each mi. The total energy of noodles showed that the differences in the composition of jackfruit seed flour and rice bran flour had an effect on the total energy. The total 
energy in F0 produced is $409.63 \mathrm{kcal}$. While in F1 it produces $402 \mathrm{kcal}$, in F2 it produces $393.3 \mathrm{kcal}$, in F3 it produces $384 \mathrm{kcal}$. The highest total energy was found in the control formulation (F0) in noodles made from wheat flour without additional ingredients of jackfruit seed flour and rice bran flour.

The recommended protein intake is $10-20 \%$ of the total daily energy per day [17]. The calculation of protein content above shows that the four noodle formulations that the researchers made were 9.65 grams, 9.39 grams, 8.87 grams, and 8.34 grams for formulations $0,1,2$, and 3 .

The recommended fat intake is $20-25 \%$ of total energy consumption per day [17]. The calculation of the fat content contained in the four noodle formulations above is F0 of 10.7 grams, F1 of 11.57 grams, F2 of 11.49 grams, and F3 of 11.41.

According to PERKENI (2019) Diabetics are recommended to consume carbohydrates as much as $45-65 \%$ of total energy per day [18]. Judging from the calculation of calories in the four noodle formulations, the results of the carbohydrate content were different. The carbohydrate content in the four formulations, respectively, is 67.18 grams, 62.6 grams, 59.05 grams, and 55.82 grams, which are the carbohydrate content of the $0.1,2$ and 3 formulations. in formulation 0 which is 67.18 grams.

According to PERKENI (2019), fiber intake in diabetics is 20-35 grams/day with a recommended fiber consumption of 25 grams/day [19]. The calculation of the fiber content contained in these four formulations is at F0 of 2.17 grams, F1 of 3.15 grams, F2 of 3.16 grams, and F3 of 3.16 grams. This shows that the fiber content in this noodle has increased with each formulation. The highest fiber content was found in $\mathrm{F} 3, \mathrm{~F} 2, \mathrm{~F} 1$, and $\mathrm{F} 0$ respectively.

\subsection{Proximate Analysis Results}

This study conducted a proximate analysis at the Laboratory of Animal Husbandry and Nutrition, University of Muhammadiyah Malang. The results obtained are as follows:

Table 3. Results of Proximate Analysis of Noodles with Jackfruit Seed Flour and Rice Bran Flour

\begin{tabular}{|l|l|l|l|l|}
\hline & \multicolumn{1}{|c|}{$\mathrm{F} 0$} & \multicolumn{1}{|c|}{$\mathrm{F} 1$} & \multicolumn{1}{|c|}{$\mathrm{F} 2$} & \multicolumn{1}{|c|}{$\mathrm{F} 3$} \\
\hline Water (\%) & $33.40 \%$ & $37.70 \%$ & $37.90 \%$ & $36.51 \%$ \\
\hline Ash (\%) & $1.98 \%$ & $2.13 \%$ & $2.34 \%$ & $2.29 \%$ \\
\hline Proteins (\%) & $9.77 \%$ & $8.50 \%$ & $8.76 \%$ & $8.12 \%$ \\
\hline Fat (\%) & $2.45 \%$ & $3.65 \%$ & $4.50 \%$ & $7.32 \%$ \\
\hline $\begin{array}{l}\text { Crude Fiber } \\
(\%)\end{array}$ & $0.36 \%$ & $0.96 \%$ & $1.53 \%$ & $1.73 \%$ \\
\hline $\begin{array}{l}\text { Carbohydrates } \\
(\%)\end{array}$ & $52.40 \%$ & $48.02 \%$ & $46.5 \%$ & $45.76 \%$ \\
\hline
\end{tabular}

The water content obtained from these four formulations produces different percentages. In formulation 0 the results obtained are $33.40 \%$. While the formulation 1 is $37.70 \%$, formulation 2 is $37.90 \%$, and formulation 3 is $36.51 \%$. Based on the results obtained in the noodle formulation, when compared with the SNI for wet noodles, the standard that must be met is $20-35 \%$. The water content that meets the standards in the above formulation is formulation 0 which is the control in this study. The shelf life of the product can be determined by analyzing the moisture content of a food ingredient [20]. The water content of a food ingredient is very important to obtain proper handling in the process of making, packaging, and distributing food. There are three forms of water contained in foodstuffs, namely free water, weakly bound water, and strongly bound water. Based on the three forms of water, free water can affect the process of spoilage of foodstuffs. In addition to water content, damage to food products can also be caused by rancidity due to oxidation or hydrolysis of food components [20] . Therefore, water content cannot be used as the only parameter to predict the speed of food spoilage.

The ash content in noodles in formulation 0 yielded $1.98 \%$. While the formulation 1 is $2.13 \%$, formulation 2 is $2.34 \%$, and formulation 3 is $2.29 \%$. Based on the results obtained in the noodle formulation, when compared with the SNI for wet noodles, the standard that must be met is a maximum of $3 \%$. The ash content that meets the standards are the four noodle formulations. The ash content in the noodles increased with the substitution of jackfruit seed flour and rice bran flour. For formulation 0 it is $1.98 \%$, formulation 1 is $2.13 \%$, formulation 2 is $2.34 \%$, and formulation 3 is $2.29 \%$. The ash content of a food has a relationship with the mineral content of a food. Rice bran is rich in minerals that act as antioxidants, the dominant content of which is tocopherol, tocotrienols, phytosterols, carotenoids, and thiamine [21]. Jackfruit seeds also have a lot of mineral content such as calcium, iron, and phosphorus [22]. So that with an increase in the composition of jackfruit seed flour and rice bran in noodles, the ash content increases.

The protein content of $\mathrm{p}$ in formulation 0 the results obtained were $9.77 \%$. While the formulation 1 is $8.50 \%$, formulation 2 is $8.76 \%$, and formulation 3 is $8.12 \%$. Based on the results obtained in the noodle formulation, when compared with the SNI for wet noodles, the standard that must be met is at least $3 \%$. Protein content that meets the standards are the four noodle formulations. Rice bran has a high protein content because it has a high lysine content. Jackfruit seeds provide rich protein, fiber and starch content [23]. According to research Nandkule et al, (2015) there was an increase in protein, fat, ash, and crude fiber in the fortification of jackfruit seed flour noodles and soybean flour, but there was a decrease in protein content day by day during storage due to proteolysis. Proteolysis is the breakdown of proteins into smaller polypeptides or amino acids [24]. 
The fat content in this study from the four formulations resulted in a different percentage of each formulation. In formulation 0 the results obtained are $2.45 \%$. While the formulation 1 is $3.65 \%$, formulation 2 is $4.50 \%$, and formulation 3 is $7.32 \%$. Fat content in wet noodles is not determined as a requirement for SNI wet noodles 01-2987-1992. The higher the addition of jackfruit seed flour, the fat content in the noodles also increases. In line with research Nandkule et al., (2015) there was an increase in protein, fat, ash, and crude fiber in the fortification of jackfruit seed flour noodles and soybean flour [24]. Likewise in bran, according to research Tuarita et al., (2017) bran itself has hypocholesterolemic activity, this compound has the effect of reducing obesity and dyslipidemia in rats with high-fat and high-fructose rations, through normalizing triglycerides, LDL, and total cholesterol in serum, and increase High Density Lipoprotein (HDL). The ability to lower triglycerides and cholesterol levels is also related to its ability to suppress lipogenesis in the liver and increase the excretion of faecal fat. The high fat content in bran is due to the characteristics of the bran itself, namely the activity of the lipase enzyme. The lipase enzyme in rice bran can hydrolyze the oil content into glycerol and free fatty acids. This conversion causes the formation of a rancid aroma [25].

The crude fiber content in formulation 0 resulted in the fiber content of $0.36 \%$. While the formulation 1 is $0.96 \%$, formulation 2 is $1.53 \%$, and formulation 3 is $1.73 \%$. Crude fiber content in wet noodles is not specified as a requirement for SNI wet noodles 01-2987-1992. There was an increase in crude fiber content of noodles substituted with jackfruit seed flour and rice bran flour. According to research Halwan \& Nisa (2015) there is an increase in crude fiber content in the addition of the proportion of bran flour. This is because bran flour has a high crude fiber content. Likewise with jackfruit seed flour [26]. According to research Theodora, Pranat, \& Swasti (2019) the more jackfruit seed flour given can have a real effect on crude fiber and soluble fiber. Crude fiber found in grains such as jackfruit seeds are cellulose, lignin, and hemicellulose. Consumption of adequate amounts of fiber can help in blood glucose control in people with diabetes mellitus [27]. According to research Soviana and Maenasari (2019) intake of fiber have been associated with glucose levels virgin $h$ in patients with type 2 diabetes mellitus [28].

Carbohydrate content in formulation 0 resulted in $52.40 \%$ fiber content. While the formulation 1 is $48.02 \%$, formulation 2 is $46.5 \%$, and formulation 3 is $45.76 \%$. Carbohydrate content in wet noodles is not specified as a requirement for SNI wet noodles 01-2987-1992. Each noodle formulation has a reduced carbohydrate content. This is in accordance with the statement Restu, Damiati, \& Ekayani (2015) that the carbohydrate content of jackfruit seed flour is 36.7 grams and has starch, while the carbohydrate content of wheat flour is 77.2 grams and has little starch [29]. According to Supriyadi (2014), in terms of carbohydrate content, it turns out that jackfruit seeds contain quite high starch, ranging from 40-50\%. Starch in jackfruit seed flour can be used to replace some of the functions of starch in wheat flour and can be used as an alternative to wheat flour [30]. According to research I \& Wirawanni (2014) there is a relationship between carbohydrate consumption and blood glucose levels. Reducing carbohydrate consumption is necessary for Type 2 Diabetes Mellitus patients, but still according to the recommended carbohydrate consumption for Diabetes Mellitus patients [18].

Based on these results, the best noodle formulation with adjustments to the dietary recommendations of diabetics regarding carbohydrates and crude fibre was in formulation 3 (30\%:5\%). According to research by Halwan and Nisa (2015), Theodora et al (2019), and Supriyadi (2014) said there was a relationship between carbohydrate and fiber content with jackfruit seeds and rice bran. The higher the composition of jackfruit seed flour and rice bran flour can affect the fiber and carbohydrate content in the noodle formulation. Recommended fiber intake for diabetics is recommended to consume the amount of 14 grams/1000 cal or 20-35 grams per day. While the recommendation for consumption of carbohydrates in diabetics is $45-65 \%$ of total energy intake, especially carbohydrates with high fiber [19]. According to research I \& Wirawanni (2014) there is a positive relationship between carbohydrate consumption, total energy, fiber, glycemic load, frequency and duration of physical exercise which together affect blood glucose levels [18].

Please note that this noodle substitution of jackfruit seed flour and rice bran flour is a heavy meal that focuses on carbohydrates. Like noodles in general, side dishes and vegetables are needed to meet the daily nutritional needs for the body. It is necessary to pay attention to the General Guidelines for Balanced Nutrition (PUGS) and the Guidelines for the Management and Prevention of Type 2 Diabetes Mellitus for dietary recommendations for diabetics.

\section{CONCLUSION}

Based on the research conducted, it can be concluded that the proximate analysis of noodles substituted with jackfruit seed flour and bran flour showed that the highest nutrient content, especially fiber, was found in noodles with substitution of jackfruit seed flour and bran flour than noodles without substitution of jackfruit seeds and bran flour. There is a decrease in carbohydrate content in each formulation of wet noodles. This research is expected to be an alternative food for diabetics. 


\section{AUTHORS' CONTRIBUTIONS}

$\mathrm{KAH}$ :concept and design the study, methodology, analysis, writing; HEW \& AK: validation, writing review, supervision

\section{ACKNOWLEDGMENTS}

The authors would like to thank Faculty of Sport Science, Universitas Negeri Malang for supporting this study.

\section{REFERENCES}

[1] Kemenkes RI. Hari Diabetes Sedunia Tahun 2018. Pus Data dan Inf Kementrian Kesehat RI. 2019;18.

[2] IDF. International Diabetes Federation - Facts \& figure. 2019. Available from: https://www.idf.org/aboutdiabetes/what-isdiabetes/facts-figures.html

[3] Trisnawati SK, Setyorogo S. Faktor Risiko Kejadian Diabetes Melitus Tipe II Di Puskesmas Kecamatan Cengkareng Jakarta Barat Tahun 2012. Vol. 5, Jurnal Ilmiah Kesehatan. 2013.

[4] Sumaryati M. Hubungan Antara Gaya Hidup Dengan Kejadian Stroke Di Ruang Rawat Inap Rsud Labuang Baji Makassar. J Ilm Kesehat Sandi Husada. 2016;4(1):20-9.

[5] Rahayu Ningrum D, Zuhrotun Nisa F, Pangastuti R, Prosiding Seminar Nasional Food Habit and Degenerative Diseases Indeks Glikemik dan Beban Glikemik Sponge Cake Sukun Sebagai Jajanan Berbasis Karbohidrat pada Subyek Bukan Penyandang Diabetes Mellitus. 2013.

[6] Hardisman H. Pencegahan Penyakit Degeneratif Dan Pengaturan Makanan Dalam Kajian Kedokteran Dan Al-Quran. J Maj Kedokt Andalas. 2015;34(1):39.

[7] Saputro PS, Estiasih T. Pengaruh Polisakarida Larut Air (PLA) dan Serat Pangan Umbi-Umbian Terhadap Glukosa Darah: Kajian Pustaka. J Pangan dan Agroindustri. 2015;3(2):756-62.

[8] Kusuma Adyana S. Indeks Glikemik dan kadar Serat Pada Mi Garut Sebagai Alternatif Makanan Pokok. 2017

[9] Saputra BF, Rachmawanti D, Praseptiangga D. Study of Sensory, Nature Chemical and Functional Properties Substitution Noodles With Red Rice Bran and Purple Sweet Potato Flour. J Teknosains Pangan. 2014

[10] Arif A, Budiyanto A, Hoerudin H. Nilai Indeks Glikemik Produk Pangan Dan Faktor-Faktor Yang Memengaruhinya. J Penelit dan Pengemb Pertan.
2013;32(3):30926

[11] Hadi N, Yusmarini, Efendi R. Pemanfaatan Tepung Biji Nangka dan tepung Jagung Dalam Pembuatan Flakes. Jom Faperta. 2017;4(2):1-12.

[12] Damayanthi E, Kustiyah L, Khalid M, Farizal H Aktivitas Antioksidan Bekatul Lebih Tinggi Daripada Jus Tomat dan penurunan Aktivitas Antioksidan Serum Setelah Intervensi inuman Kaya Antioksidan [Internet]. Journal of Nutrition and Food. 2010

[13] Liandani W, Zubaidah E. Formulasi Pembuatan Mie Instan Bekatul (Kajian Penambahan Tepung Bekatul Terhadap Karakteristik Mie Instan). J Pangan dan Agroindustri [Internet]. 2015 Jan;3:174-85. Available from: https://jpa.ub.ac.id/index.php/jpa/article/view/122/ 140

[14] Aprilianti N, Miftah AM, Arumsari A. Pengembangan Formula Mi dengan Tepung Biji Nangka, Pati Jagung dan Wortel. Pros Farm Vol 5 , No 2, Pros Farm (Agustus, 2019); 281-287. 2019 Aug 8;

[15] Festiawan R, Arovah NI. Pengembangan "Buku Saku Pintar Gizi" Untuk Siswa SMP: Alternatif Media Pembelajaran untuk Meningkatkan Pengetahuan Gizi Olahraga. Phys Act J 2020;1(2):188.

[16] Miranda D. Pengembangan Buku Cerita Berbasis Pendidikan Karakter Untuk Meningkatkan Kreativitas Aud. J Visi Ilmu Pendidik. 2018;10(1):18.

[17] Kemenkes RI. Peraturan Menteri Kesehatan Republik Indonesia Nomor 28 Tahun 2019. $2019 ; 12-4$

[18] I FR, Wirawanni Y. Hubungan Konsumsi Karbohidrat, Konsumsi Total Energi, Konsumsi Serat, beban Glikemik dan Latihan Jasmani dengan Kadar Glukosa Darah pada Pasien Diabetes Mellitus Tipe 2 U. Jnh. 2014;2(3):89842.

[19] Susilowati A, Rachmat B, Larasati RA. Hubungan Pola Konsumsi Serat Dengan Kontrol Glikemik Pada Diabetes Tipe 2 (T2D) Di Kecamatan Bogor Tengah [Relationship of Fiber Consumption Patterns To Glycemic Control in Type 2 Diabetes (T2D) in Central Bogor Sub-District]. Penelit Gizi dan Makanan (The J Nutr Food Res. 2020;43(1):41-50

[20] Nashriana N, Wirjatmadi B, Adriani M. Combined Food (Bekatul dan Lemak) Menurunkan Kadar Kolesterol Total , Trigliserida , dan LDL pada Tikus Galur Wistar Combined Food ( Rice Bran and Fat ) Reduce of the Total Cholesterol Levels Triglycerides, and LDL of Wistar Strain Rats. J 
Kedokt Brawijaya. 2015;28(3):208-12.

[21] Luthfianto D, Noviyanti RD, Kurniawati I. Karakterisasi Kandungan Zat Gizi Bekatul pada Berbagai Varietas Beras di Surakarta. J Kesehat. 2017;2(1):371-6.

[22] Nusa, Mhd I, Fuadi M, Fatimah S. Studi Pengolahan Biji Buah Nangka Dalam Pembuatan Minuman Instan. J Agrium. 2014;19.

[23] Waghmare R, Memon N, Gat Y, Gandhi S, Kumar V, Panghal A. Jackfruit seed: An accompaniment to functional foods. Brazilian $\mathrm{J}$ Food Technol. 2019;22:1-9.

[24] Nandkule VD, Masih D, Sonkar C, Patil DD. Development and Quality Evaluation of Jackfruit Seed and Soy Flour Noodles. Int J Sci Eng Technol. 2015;3(3):802-6.

[25] Tuarita MZ, Sadek NF, Sukarno, Yuliana ND. Pengembangan Bekatul sebagai Pangan Fungsional: Peluang, Hambatan, dan Tantangan Rice Bran Development as Functional Foods: The Opportunities, Obstacles, and Challenges. J Pangan. 2017;26(22).

[26] Halwan CA, Nisa FC. Making of Gembili and Rice Bran Noodles ( Study of Proportion Wheat Flour: Gembili and additioning of Rice Bran). J Pangan dan Agroindustri. 2015;3(4):1548-59.

[27] Theodora A, Pranat FS, Swasti YR. Substitusi Tepung Biji Nangka (Artocarpus heterophyllus Lamk.) Dalam Pembuatan Kwetiau Basah Dengan Penambahan Ekstrak Secang (Caesalpinia sappan L.). Sains dan Teknol. 2019;3(1).

[28] Soviana E, Maenasari D. Asupan Serat, Beban Glikemik Dan Kadar Glukosa Darah Pada Pasien Diabetes Melitus Tipe 2. J Kesehat. 2019;12(1):1929.

[29] Restu N, Damiati, Ekayani IAPH. Pemanfaatan Tepung Biji Nangka Menjadi Kue Pia Kering. EJournal Pemanfaat Tepung Biji Nangka Menjadi Kue Pia Kering Univ Pendidik Ganesha Jur Pendidik Kesejaht Kel. 2015;XI:1-8.

[30] Supriyadi A. Pengaruh Substitusi Tepung Biji Nangka (Artocarpus Heterphyllus) Terhadap Mutu Organoleptik Kue Onde-onde Ketawa. e-journal boga. 2014;225-33. 